\title{
Stres Kerja dan Keterikatan Kerja pada Karyawan Swasta: Peran Mediasi Kesejahteraan di Tempat Kerja
}

\author{
Job Stress and Work Engagement to Private Employees: \\ Mediation Role of Workplace Well-Being
}

\author{
Vissy Vandiya ${ }^{1}$, Arum Etikariena ${ }^{1}$ \\ ${ }^{I}$ Faculty of Psychology, Universitas Indonesia, Kampus Baru UI, Depok, Indonesia \\ vissy.vandiva@gmail.com; arum.hidayat@gmail.com
}
KATA KUNCI Stres kerja, Kesejahteraan di tempat kerja, Keterikatan Kerja, analisis mediasi
KEYWORDS Job stress, Workplace well-being, Work Engagement, Mediation Analysis

ABSTRAK Karyawan yang memiliki keterikatan kerja yang rendah dapat merugikan perusahaan yang salah satunya ditunjukan dengan menurunnya performa kerja dan tidak produktif saat bekerja. Stres kerja dikatakan dapat mengakibatkan menurunnya keterikatan kerja. Stres kerja juga merupakan masalah utama dalam kesejahteraan individu dapat berpengaruh pada kondisi fisik, psikologis individu dan organisasi yang akan mempengaruhi keterikatan kerja. Tujuan dari penelitian ini adalah untuk membuktikan variabel kesejahteraan di tempat kerja sebagai mediator variabel stres kerja dengan keterikatan kerja. Pengambilan data pada penelitian dengan menyebar kuesioner secara daring (online) dan anonim dengan menggunakan gform ke para karyawan swasta di Jakarta antara umur 25 - 49 tahun, dengan pengalaman kerja minimal 2 tahun, serta minimal tingkat pendidikannya adalah S1. Jumlah responden yang diolah datanya sebanyak 200 orang dengan jumlah responden perempuan sebanyak 120 orang dan laki-laki sebanyak 80 orang. Penelitian ini menggunakan desain penelitian kuantitatif dengan menggunakan analisis mediasi dari Hayes pada PROCESS SPSS versi 23. Peneliti menggunakan skala alat ukur Job Stres Scale untuk stres kerja (IV) (cronbach's alpha $=.830)$, WWBI (Workplace Well-Being Index) untuk kesejahteraan di tempat kerja (MV) ( cronbach's alpha $=.863$ ) dan UWES (Utrecht Work Engagement Scale) untuk keterikatan kerja $(D V)$ (cronbach's alpha $=.922)$. Hasil penelitian menunjukan bahwa kesejahteraan di tempat kerja sebagai variabel mediasi antara stress kerja dengan keterikatan kerja dengan nilai Effect $=-.151, S E=.045$, CI [-.2454, -.0687].

ABSTRACT Employees who have low work engagement can harm the company, it can be shown by the decreasing of work performance and unproductive. Job stress can impact in decreased attachment of work. Job stress is also a major problem in the individual well-being that can affect the physical, psychological condition of the individual and the organization and also 
will affect the work engagement. The purpose of this study is to prove the variable of workplace wellbeing as a mediator of job stress variables with work engagement. The collecting data on the research is by spreading the online questionnaire which is gform and anonymously to the private employees in Jakarta, the ages 25-49 years, with working experience of at least 2 years, and minimum education level is bachelor. The number of respondents who data was processed are 200 people with the number offemale respondents are 120 people and men are 80 people. This research uses quantitative research design using mediation analysis from Hayes in PROCESS in SPSS version 23. The scales that researcher used are Job Stress Scale for job stress (IV) (cronbach's alpha $=0.830)$, WWBI (Workplace Well-Being Index) for workplace well-being (MV) (cronbach's alpha $=0.863$ ) and UWES (Utrecht Work Engagement Scale) for work engagement $(D V)($ cronbach's alpha $=0.922)$. The results showed that workplace well-being as a mediation between job stress and work engagement variables with the value of Effect $=-.151$, $S E=.045, C I[-.2454,-.0687]$.

\section{PENDAHULUAN}

Karyawan yang memiliki keterikatan kerja (work engagement) yang buruk terhadap perusahaan, dapat merugikan perusahaan karena adanya penurunan kesejahteraan karyawan serta produktifitasnya (Shuck \& Jr., 2014). Karyawan yang tidak memiliki keterikatan kerja dengan perusahaan tempat dirinya bekerja, akan dengan mudah mengundurkan diri dari perusahaan tersebut dan mencari pekerjaan di perusahaan lain. Hal ini menjadi suatu masalah bagi perusahaan karena perusahaan mengalami kerugian baik tenaga, waktu maupun materi. Oleh karena itu peran sumber daya manusia yaitu karyawan yang merupakan aset perusahaan sangatlah penting, terutama karyawan yang memiliki keterikatan kerja. Keterikatan kerja menjadi salah satu cara perusahaan untuk mengukur investasi di human capital (Orgambídez-Ramos, Borrego-Alés, \& Mendoza-Sierra, 2014). Karyawan yang memiliki keterikatan kerja akan merasakan lebih berenergi, memiliki hubungan efektif dengan pekerjaannya (Hakanen \& Schaufeli, 2012). Tentu saja perusahaan mengharapkan agar mayoritas karyawannya memiliki keterikatan kerja, hanya saja hal tersebut

Correspondence:

Vissy Vandiya, Universitas Indonesia, Kampus Baru UI, Depok, Indonesia Tel. 0812-9422263, Email: vissy.vandiya@gmail.com tidak selalu dapat terwujud dan menjadi tantangan bagi perusahaan.

Bakker, Schaufeli, Leiter dan Taris (2008) menyebutkan bahwa keterikatan merupakan suatu konsep unik yang paling baik diprediksi oleh sumber daya pekerjaan (otonomi, pengawasan, pembinaan, umpan balik kinerja) dan sumber daya personal, contohnya optimisme, self-efficacy (Suatu kepercayaan bahwa individu dapat melakukan sesuatu dengan sukses (Greenberg, 2011)), self-esteem (seberapa tinggi individu memandang dirinya sendiri (Greenberg, 2011)). Hal tersebut menunjukan bahwa keterikatan kerja sangat penting untuk perusahaan karena karyawan yang memiliki keterikatan kerja yang tinggi akan meningkat produktifitasnya yang berguna untuk perusahaan.

Saat ini, perusahaan tidak lagi mencari calon karyawan berdasarkan kemampuan semata, tetapi juga berdasarkan kemampuan calon karyawan untuk terlibat secara penuh kepada pekerjaannya, proaktif, serta memiliki komitmen tinggi terhadap standar kualitas kinerja mereka (Kurniawati, 2014).

Khairuddin (2017) mengungkapkan bahwa ada beberapa penelitian yang menunjukan bahwa adanya pengaruh negatif dari stresor (sumber stres) dengan 
keterikatan kerja. Berkebalikan dengan karyawan yang merasakan stres, karyawan yang memiliki keterikatan kerja akan merasa energik dan efektif bekerja, memandang pekerjaannya sebagai suatu tantangan dibandingkan dengan merasakan stres dan tuntutan (Schaufeli, 2012). Tingkat stres yang tinggi di tempat kerja akan berdampak negatif dengan keterikatan kerja (Frith, 2017). Rothmann (2008) serta Narainsamy dan Westhuizen (2013) juga mengungkapkan bahwa stres memiliki hubungan yang berbanding terbalik dengan keterikatan kerja. Pada penelitian ini, peneliti memilih stres kerja sebagai variabel prediktor terhadap keterikatan kerja karena berdasarkan penemuan-penemuan tersebut yang menunjukan bahwa stres kerja memiliki pengaruh negatif dengan keterikatan kerja, dan hal tersebut akan berdampak buruk bagi karyawan dan perusahaan apabila hal tersebut tidak diatasi.

Lazarus dan Folkman (1984, dalam

Bell, Rajendran, dan Theiler, 2012) mendefinisikan stres sebagai hubungan antara individu dengan lingkungannya yang dinilai sebagai keadaan yang berbahaya untuk kesejahteraan individu. Sedangkan stres kerja (job stress) didefinisikan sebagai sesuatu di lingkungan kerja yang dipersepsikan sebagai ancaman atau tuntutan, atau sesuatu di tempat kerja yang menyebabkan ketidaknyamanan yang dirasakan oleh karyawan (Bell, Rajendran, \& Theiler, 2012). Stres yang diakibatkan karena beban pekerjaan atau stres kerja adalah tekanan psikologis (psychological distress) atau ketegangan yang timbul dari stresor individu dan organisasi di tempat kerja (Finney, Stergiopoulos, Hensel, Bonato, \& Dewa, 2013). Stres kerja juga disebutkan sebagai reaksi individu terhadap karakteristik lingkungan kerja yang dirasakan mengancam secara emosional dan fisik (Arshadi \& Damiri, 2013). Stres tersebut terjadi jika tuntutan pada individu tidak sesuai dengan sumber daya yang tersedia atau memenuhi kebutuhan dan motivasi individu. Stres tersebut akan timbul jika beban kerja terlalu banyak untuk jumlah karyawan serta waktu yang tersedia. Sama halnya dengan tugas yang membosankan dan berulang yang tidak menggunakan keterampilan dan pengalaman potensial individu juga akan menyebabkan stres (Stranks, 2005).

Berdasarkan pengertian dari Arnold, dkk., (2010), stres kerja adalah suatu emosi negatif yang didapat dari interaksi dengan orang lain, lingkungan tempat ia bekerja dan juga karena tekanan kerja. Selain itu juga lingkungan kerja yang kompetitif menambah beban pada karyawan yang target kerja semakin tinggi (Iqbal, Khan, \& Iqbal, 2012). Stres kerja dianggap sebagai masalah utama dalam keselamatan kerja dan aspek kesehatan terutama kesejahteraan di organisasi (Ikonne, 2015). Kesejahteraan psikologis yang dirasakan karyawan, dipengaruhi oleh stres, dan jika hal tersebut dibiarkan maka akan mempengaruhi kesehatan fisik, psikologis individu dan perusahaan dan menjadi buruk (Khairuddin \& Nadzri, 2017; Arnold, et al., 2010). Masalah yang berhubungan dengan stres kerja dan karier dapat secara negatif memengaruhi kesejahteraan dan keterikatan karyawan dalam aktivitas kerja mereka (Coetzee \& Villiers, 2010). Stres kerja mengakibatkan masalah di perusahaan yaitu berupa ketidakhadiran (absenteesism), turnover, dan menurunnya performa kerja. Hal ini membuat karyawan yang bekerja pun menjadi kurang produktif (Ikonne, 2015). Karyawan yang kurang produktif, akan berdampak buruk terhadap perusahaan.

Karyawan yang memiliki keterikatan dengan perusahaan tempat dirinya bekerja, merasakan emosi yang positif dan kondisi fisik dan psikologis yang baik (Robertson, Birch, \& Cooper, 2012). Hal ini menunjukan bahwa karyawan yang memiliki kesejahteraan psikologis, akan memengaruhi keterikatan kerja. Karyawan yang memiliki tingkat kesejahteraan psikologis yang tinggi akan lebih sehat (fisik dan psikologis), memiliki hidup yang lebih bahagia serta lebih produktif dibandingkan dengan karyawan yang memiliki tingkat kesejahteraan psikologis yang rendah 
(Robertson, Birch, \& Cooper, 2012). Karyawan yang memiliki tingkat kesejahteraan psikologis yang tinggi akan mencerminkan perilaku positif yang akan mendukung keterlibatan karyawan yang lebih kuat (Shuck \& Jr., 2014). Hal tersebut tentu saja akan berdampak positif untuk perusahaan.

Berbagai faktor yang memengaruhi keterikatan kerja seperti yang sudah disebutkan sebelumnya adalah stres kerja (job stress) yang mempengaruhi kesejahteraan, terutama kesejahteraan di tempat kerja (workplace well-being). Karyawan yang mengalami stres kerja, akan memengaruhi kesehatannya salah satunya detak jantung yang tidak menentu yang akan mengakibatkan susah untuk berbicara dan berpikir secara logis (Robbins \& Judge, 2015). Stres kerja merupakan dampak negatif terhadap kesejahteraan karyawan baik fisik maupun psikologis (Bell, Rajendran, \& Theiler, 2012). Kondisi kerja (pekerjaan maupun tempat kerja) berhubungan dengan kesejahteraan karena merupakan salah satu faktor yang mempengaruhi kesehatan karyawan (Arnold, et al., 2010). Kondisi di tempat kerja yang memberdayakan karyawan untuk mengoptimalkan kinerja kerja diketahui dapat meningkatkan kesejahteraan karyawan (Laschinger \& Fida, 2014). Kondisi di tempat kerja tersebut berupa iklim dan kondisi di tempat kerja serta hubungan dengan individu lainnya. Iklim dan kondisi tempat bekerja, serta perbedaan individu (perilaku, kepribadian, strategi untuk coping yaitu cara untuk menurunkan stres, kemampuan dan keterampilan) akan mempengaruhi kesejahteraan di tempat kerjaserta tingkat stres pada karyawan (Arnold, et al., 2010). Kondisi tersebut sangat penting untuk dipertahankan dalam kondisi yang baik untuk karyawannya agar karyawan dapat bekerja dengan baik, nyaman, serta menurunnya stres kerja. Pada penelitian yang dilakukan oleh Shuck dan Jr (2014) mendapatkan hasil bahwa karyawan yang memiliki keterikatan yang tinggi menunjukan kesejahteraan psikologis dan prestasi yang tinggi. Maka dikatakan bahwa keterikatan kerja merupakan keadaan motivasi afektif dari kesejahteraan yang berhubungan dengan pekerjaan (Workrelated Well-Being) (Chacko, 2015).

Stres kerja perlu diatasi oleh perusahaan jika ingin memiliki karyawan yang sejahtera dan memiliki keterikatan kerja serta dapat memberikan keuntungan untuk perusahaan. Karyawan yang memiliki keterikatan kerja yang kuat dengan organisasi, maka karyawan tersebut akan lebih mudah mengelola hubungan kerja dengan rekan kerja yang lain, stres kerja, serta perubahan yang akan dihadapi (Meyer, 2012). Hal tersebut yang menjadikan alasan peneliti memilih variabel-variabel tersebut. Pada penelitian ini, stres kerja menjadi variabel bebas, keterikatan kerja menjadi variabel terikat, dan kesejahteraan di tempat kerja menjadi variabel mediator.

Pertanyaan penelitian pada penelitian ini adalah: Apakah Kesejahteraan di Tempat kerja memediasi stres kerja dan keterikatan kerja?

Tujuan dari penelitian ini adalah untuk melihat variabel kesejahteraan di tempat kerja memediasi variabel stres kerja dengan variabel keterikatan kerja. Manfaat dari penelitian ini adalah jika variabel kesejahteraan kerja merupakan mediator antara variabel stres kerja dan variabel keterikatan kerja maka setiap organisasi harus memperhatikan kesejahteraan karyawan dengan membuat karyawan tidak stres dan bahagia agar karyawan memiliki keterikatan kerja dengan perusahaan tempat ia bekerja.

\section{Keterikatan Kerja (Work Engagement)}

Kesejahteraan yang berhubungan dengan pekerjaan, tidak hanya berhubungan pada burnout (kelelahan yang secara fisik atau psikologis) dikarenakan kerja yang berlebihan atau stres (yang merupakan keadaan negatif) tetapi juga dengan keterikatan kerja (yang merupakan keadaan positif). Keterikatan dikatakan sebagai keadaan psikologis yang aktif dan energik yang mendorong mobilisasi sumber daya 
bahkan dalam kondisi mental yang menantang. Oleh sebab itu keterikatan kerja akan membuat organisasi menjadi positif (Hakanen \& Schaufeli, 2012). Karyawan yang memiliki keterikatan kerja akan merasakan "flow" yaitu keadaan yang melibatkan konsentrasi penuh dalam mengerjakan pekerjaan yang tidak sadar waktu cepat berlalu (Robertson, Birch, \& Cooper, 2012). Hal ini sesuai dengan karakteristik dari keterikatan kerja yaitu semangat (vigor), dedikasi (dedication), dan absorpsi (absorption). Karakteristik semangat (vigor) adalah tingkat energi yang tinggi dan ketahanan mental saat bekerja, memiliki keinginan untuk bekerja lebih giat, serta tetap gigih walau menghadapi kesulitan. Dedikasi (dedication) mengacu pada keterlibatan yang mendalam pada pekerjaan dan mengalami rasa signifikansi, antusias, terinspirasi, bangga serta tertantang. Absorpsi (Absorption) dikarakteristikan dengan berkonsentrasi secara penuh dan dengan senang hati larut dengan pekerjaan sehingga waktu terasa berlalu dengan cepat dan sulit untuk melepaskan diri dari pekerjaan tersebut (Schaufeli, Bakker, \& Salanova, 2006). Keterikatan kerja diprediksi dengan kuat oleh sumber daya pekerjaan yang memenuhi kebutuhan dasar individu untuk otonomi psikologis, kompetensi, serta keterkaitan dengan peningkatan kesejateraan dan meningkatkan motivasi intrinsik (Coetzee \& Villiers, 2010).

\section{Stres Kerja (Job Stress)}

Stres adalah respon adaptif terhadap situasi yang dianggap menantang atau mengancam kesejahteraanindividu (Robbins \& Judge, 2015). Terdapat dua tipe stres yaitu positif (eustress) dan negatif (distress). Dikatakan stres yang negatif apabila terdapat penyimpangan dalam perilaku, fisiologis dan psikologis. Stres yang positif dapat mengaktifkan dan memotivasi seseorang untuk mencapai tujuannya, merubah lingkungannya dan berhasil dalam menghadapi tantangan hidup (Robbins \& Judge, 2015). Stres pada tiap orang berbeda- beda dan bersifat subjektif. Jika terdapat dua orang yang mengalami stres yang sama, tingkat atau jenis stres yang dialami oleh satu individu belum tentu sama dengan yang dirasakan oleh individu lainnya. Stres mengacu pada tekanan eksternal yang berdampak pada tubuh dan disebut sebagai stresor (Krohne, 2002). Krohne (2002) menyebutkan bahwa hubungan antara stresor dan stres dibagi menjadi dua kategori yaitu pendekatan ke stres sistemik (systemic stress) yang berdasarkan fisiologi dan psikobiologi (teori dari Selye) dan pendekatan ke stres psikologis (psychological stress) yang terdiri dari dua konsep yaitu penilaian (appraisal) dan cara menurunkan stres (coping) yang dikembangkan dalam area psikologi kognitif (teori dari Lazarus).

Pada saat individu mengalami stres, maka tubuhnya akan mengalami reaksi dan reaksi tersebut merupakan tahapan dari sindrom adaptasi umum (general adaptation syndrome (GAS)) yang ditemukan oleh Hans Selye pada tahun 1936. Tiga tahapan tersebut adalah (1) Reaksi alarm (Alarm reaction) adalah tahap kejutan (initial shock phase) yang meningkatkan adrenalin, kemudian tahap penghalang (countershock phase) yang merupakan proses difensif awal. (2) Perlawanan (Resistance) adalah tahap reaksi alarm menghilang dan mulai dapat beradaptasi dengan stresornya. (3) Kelelahan (Exhaustion) adalah tahap individu tersebut tidak mampu beradaptasi dengan stresornya dan tahap pertama yaitu reaksi alarm kembali muncul tetapi tidak dapat melakukan perlawanan (resistance). Hal tersebut dapat merusak jaringan tubuh dan jika berlanjut akan menyebabkan kematian (Krohne, 2002).

Menurut Bell, Rajendran, dan Theiler (2012), stres kerja adalah sesuatu di lingkungan kerja yang dipersepsikan sebagai ancaman atau tuntutan, atau suatu keadaan di tempat kerja yang menyebabkan ketidaknyamanan yang dirasakan oleh karyawan. Stres kerja terdiri dari (1) Tuntutan (demands) yang terdiri dari tanggung jawab, tekanan, kewajiban, dan 
hal-hal yang tidak terduga yang dihadapi karyawan dan (2) Sumber daya (resources) yang merupakan hal-hal di dalam kendali karyawan yang dapat digunakan untuk menyelesaikan tuntutan (Robbins \& Judge, 2015). Menurut Stranks (2005), stresor di tempat kerja adalah (1) Pekerjaan: pekerjaan yang terlalu banyak atau terlalu sedikit, kondisi kerja yang buruk, tenggat waktu, pengambilan keputusan. (2) Peran di organisasi: konflik dan ambiguitas jabatan, tanggung jawab terhadap orang lain, tidak diikutsertakan dalam pengambilan keputusan. (3) Perkembangan karir: promosi yang berlebihan atau kurang, kurangnya keamanan kerja, terhalangnya ambisi kerja. (4) Struktur dan iklim organisasi: kurangnya konsultasi yang efektif, pembatasan perilaku, politik kerja. (5) Hubungan dalam organisasi: hubungan yang buruk dengan atasan, kolega, bawahan serta kesulitan dalam mendelegasikan tanggung jawab.

Coping atau cara menurunkan stres dapat dibedakan menjadi dua macam yaitu problem-focused strategies yang fokus pada masalah utama dari stres tersebut dan emotion-focused strategies yang fokus akan bagaimana perasaan individu tentang situasi yang penuh tekanan atau stres. Hasil dari strategi tersebut sulit diprediksi selain karena strategi yang dipilih individu tersebut juga seberapa efektif digunakannya (Arnold, et al., 2010).

\section{Kesejahteraan di Tempat Kerja (Workplace Well-Being)}

Kesejahteraan di tempat kerja merupakan core affect serta kepuasan intrinsik dan ekstrinsik dari nilai pekerjaan tersebut (Page, 2005 dalam Moulisa \& Sjabadhyni, 2013). Core affect adalah perasaan sejahtera secara umum yang terlihat dari suasana hati dan mood, faktor intrinsik adalah penghargaan psikologis dari pekerjaan seperti tanggung jawab dan prestasi, sedangkan faktor ekstrinsik adalah faktor eksternal yang mendorong individu untuk bekerja yaitu upah (Page K., 2005). Kesejahteraan di tempat kerja meliputi kepuasan kerja (job satisfaction), evaluasi diri (core self-evaluations), tujuan yang konsisten dengan dirinya (self-concordant goals) dan motivasi untuk mencapai sebuah prestasi (achievement motivation) yang terdiri dari nilai kerja (Page K., 2005).

Menurut Page dan Vella-Brodrick (2009), kesejaheraan di tempat kerja merupakan salah satu dari tiga komponen dasar kesejahteraan karyawan (employee well-being). Dua komponen dasar lainnya adalah kesejahteraan psikologis (psychological well-being) dan kesejahteraan subjektif (subjective wellbeing). Kesejahteraan di tempat kerja merupakan pengembangan teori dari kesejahteraan subjektif yang berfokus di kehidupan kerja yang dikembangkan oleh Page (2005). Kesejahteraan psikologis menekankan pada keadaan fungsi psikologis dan pemenuhan potensi pribadi (Zheng, Zhu, Zhao, \& Zhang, 2015). Kesejahteraan psikologismemiliki dua komponen penting yaitu aspek tujuan atau purposif (eudemonic) dan aspek emosional (hedonic). Aspek tujuan dapat dilihat dari individu merasakan aktifitas kerjanya memiliki tujuan yang jelas. Sedangkan aspek emosional dapat dilihat bagaimana emosi dan mood individu serta kepuasan hidup secara keseluruhan (Arnold, et al., 2010). Pengertian dari kesejahteraan karyawan merupakan pemahaman yang dimengerti oleh semua orang tetapi tidak ada yang dapat memberikan definisi secara tepat (Zheng, Zhu, Zhao, \& Zhang, 2015). Kesejahteraan subjektif adalah evaluasi keseluruhan akan kehidupan dan pengalaman emosional seseorang, yang meliputi penilaian secara luas yaitu kepuasan hidup dan penilaian kepuasan akan kesehatan, serta perasaan spesifik yang mencerminkan bagaimana orang bereaksi terhadap suatu kejadian dan keadaan dalam kehidupan mereka (Diener, et al., 2016). Pada penelitian ini akan difokuskan pada kesejahteraan di tempat kerjakarena berfokus pada kesejahteraan di lingkungan kerja. 


\section{Peran Stres Kerja terhadap Keterikatan Kerja Melalui Kesejahteraan di Tempat Kerja}

Karyawan yang memiliki keterikatan

kerja akan bekerja dengan semangat berdedikasi dan berkonsentrasi penuh saat bekerja. Karyawan yang memiliki keterikatan kerja menunjukan motivasi instrinsik (Shimazu, Schaufeli, Kubota, \& Kawakami, 2012; Pocnet, et al., 2015). Motivasi instrinsik merupakan salah satu faktor dari core affect yang merupakan dimensi dari kesejahteraan di tempat kerja. Karyawan yang sejahtera di tempat kerja tidak hanya ditandai dengan selalu hadir di tempat kerja tetapi dengan menyiratkan kesehatan fisik, mental dan emosional yang optimal. Karyawan yang sejahtera di tempat kerja adalah karyawan yang sehat dan sejahtera baik psikologis, sosial dan emosional. Kesejahteraan psikologis mengacu pada penerimaan diri, perkembangan diri, tujuan hidup, penguasaan lingkungan (individu mampu memanfaatkan lingkungan untuk memenuhi kebutuhannya), otonomi, serta hubungan positif dengan orang lain. Kesejahteraan sosial mengacu pada penerimaan sosial, kontribusi sosial, integrasi sosial, aktualisasi sosial, dan koherensi sosial. Sedangkan Kesejahteraan emosional mengacu pada perasaan positif (positif affect), perasaan negatif (negative affect), kepuasan hidup serta kebahagian (Rothmann \& Cooper, 2008).

Rothmann dan Cooper (2008) juga menyatakan bahwa kesejahteraan di tempat kerja, berhubungan erat dengan eustress (positif) dan distress (negative) yang merupakan tipe dari stres. Sedangkan keterikatan kerja dianggap sebagai bentuk dari eustress di tempat kerja karena keterikatan kerja adalah suatu kondisi pikiran terkait pekerjaan yang positif dan memuaskan yang ditandai dengan semangat (vigor), dedikasi (dedication) dan absorpsi (absoption) (Schaufeli, 2012). Berdasarkan teori-teori yang sudah dikemukakan tersebut dapat dikatakan bahwa stres kerja mempengaruhi keterikatan kerja baik secara langsung maupun melalui variabel lain yaitu kesejahteraan di tempat kerja (mediasi). Maka pada penelitian ini, peneliti menggunakan model mediasi sederhana dengan stres kerja sebagai IV (Independent Variable atau Variabel Bebas), keterikatan kerja sebagai DV (Dependent Variable atau Variabel Terikat) dan kesejahteraan di tempat kerja sebagai MV (Mediator Variable atau Variabel Mediator). Analisis mediasi adalah metode statistik yang digunakan untuk membantu menjawab pertanyaan mengenai bagaimana variabel $\mathrm{X}$ mentransmisikan efeknya pada Y (Hayes, 2013).

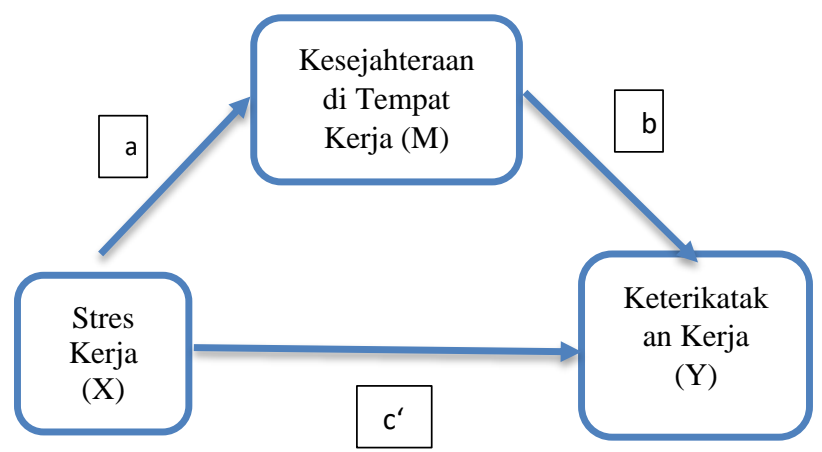

Gambar 1. Kerangka pemikiran pengaruh stres kerja terhadap keterikatan kerja yang dimediasi oleh kesejahteraan di tempat kerja.

\section{METODE PENELITIAN \\ Desain Penelitian}

Pada penelitian ini menggunakan metode kuantitatif dengan desain penelitian non-eksperimental karena pada penelitian ini ingin melihat hubungan antara variabel yang satu dengan yang lainnya tanpa perlu menjelaskan hubungannya dan tidak melakukan kontrol ataupun manipulasi terhadap variabel penelitan (Gravetter \& Forzano, 2012). Jenis sampling yang digunakan adalah nonprobability sampling yaitu populasi tidak sepenuhnya diketahui, probabilitas individu tidak dapat diketahui, dan metode pengambilan sampel didasarkan pada faktor-faktor seperti akal sehat atau kemudahan, dengan upaya untuk menjaga keterwakilan dan menghindari bias 
(Gravetter \& Forzano, 2012).Terdapat tiga variable dalam penelitian ini yaitu variabel stres kerja, kesejahteraan di tempat kerja, dan keterikatan kerja. Penelitian ini dilakukan dengan menyebarkan tiga macam kuesioner yaitu job stres scale untuk variabel stres kerja, WWBI (Workplace Well-Being Index) untuk variabel kesejahteraan di tempat kerja dan UWES (Utrecht Work Engagement Scale) untuk variabel keterikatan kerja. Analisis data dari kuesioner ini akan diolah dengan SPSS versi 23. Peneliti ingin membuktikan variabel kesejahteraan di tempat kerja memediasi variabel stres kerja terhadap keterikatan kerja. Teknik pengolahan data yang digunakan untuk membuktikan hal tersebut dengan menggunakan PROCESS oleh Hayes versi 3.00 di SPSS versi 23.

\section{Partisipan Penelitian}

Berdasarkan teori-teori tersebut, peneliti ingin melakukan analisa hipotesis bahwa jika karyawan yang memiliki stres kerja maka kesejahteraan di tempat kerja yang dirasakan karyawan akan terganggu yang berdampak pada keterikatan kerja. Kesejahteraan karyawan di tempat kerja menjadi mediator untuk stres kerja dan keterikatan kerja. Untuk membuktikan hipotesis tersebut, maka akan dilakukan penelitian dengan menyebarkan kuesioner kepada 200 karyawan yang memiliki karakteristik sebagai berikut:

1. Karyawan swasta di Jakarta

Karyawan yang bekerja di perusahaan swasta memiliki deskripsi pekerjaan (job description atau jobdesc) lebih jelas dan tetap, dengan upah minimal menyesuaikan dengan UMR (Upah Minimum Regional).

2. Min. Pendidikan lulus S1 (Strata 1)

Pekerjaan dengan pendidikan minimal S1 diasumsikan posisi administrasi yang hampir selalu berada di kantor.

3. Usia 25 - 49 thn

Usia mulai dari 25 tahun sampai 49 tahun merupakan usia produktif yang masih aktif bekerja (belum memasuki pensiun).

4. Bekerja min. 2 thn

Karyawan yang sudah bekerja minimal 2 tahun diasumsikan sudah mulai merasakan kehidupan kerja baik yang bersifat positif (seperti mendapatkan upah yang sesuai, rekan kerja yang baik) dan negatif (seperti sering lembur karena pekerjaan yang menumpuk).

5. Bukan pekerja

shift/magang/lapangan

Para pekerja shift atau magang atau lapangan, diasumsikan memiliki tingkat pendidikan yang dibawah S1 atau pekerja yang umurnya dibawah 25 tahun dan masa bekerja yang dibawah 2 tahun (contohnya pekerja magang adalah mahasiswa yang sedang menjalankan tugas akhir dengan bekerja di perusahaan selama kurun waktu tertentu).

\section{Instrumen Penelitian}

Alat ukur yang digunakan untuk mengukur stres kerja yang dihadapi oleh individu di tempat kerjanya dan pekerjaannya akan menggunakan alat ukur Job Stres Scale yang dikembangkan oleh Shukla dan Srivastava (2016) yang terdiri dari empat dimensi yaitu job stres scale (9 item), role expectation conflict (5 item), coworker support (4 item), dan work-life balance 4 item). Menggunakan skala Likert yang terdiri dari skala 1 adalah Sangat Tidak Setuju, skala 2 adalah Tidak Setuju, skala 3 adalah Agak Tidak Setuju, skala 4 adalah Agak Setuju, skala 5 adalah Setuju dan skala 6 adalah Sangat Setuju untuk dimensi job stres scale, role expectation conflict dan work-life balance. Skala untuk ketiga dimensi tersebut berdasarkan Shukla dan Srivastava (2016) adalah sebanyak 5 skala, tetapi pada penelitian ini peneliti menggunakan 6 skala untuk menghindari kecenderungan responden memilih skala tengah. Untuk dimensi coworker support, menggunakan skala Likert yang terdiri dari skala 1 adalah Tidak Pernah, skala 2 adalah 
Jarang, skala 3 adalah Terkadang, skala 4 adalah Sering, skala 5 adalah Sangat Sering dan skala 6 adalah Selalu.

Alat ukur yang dipakai untuk mengukur kesejahteraan individu di tempat kerjanya akan menggunakan alat ukur WWBI (Workplace Well-Being Index) dari Page (2005). WWBI ini terdiri dari 1 item core affect, 5 item faktor intrinsik dan 8 item factor ekstrinsik. Menggunakan skala Likert dari skala 1 (Sangat Tidak Setuju) sampai dengan skala 6 (Sangat Setuju). Skala Likert untuk alat ukur variabel ini terdiri dari skala 1 adalah Sangat Tidak Setuju, skala 2 adalah Tidak Setuju, skala 3 adalah Agak Tidak Setuju, skala 4 adalah Agak Setuju, skala 5 adalah Setuju dan skala 6 adalah Sangat Setuju.

Alat ukur yang digunakan untuk mengukur keterikatan individu dengan pekerjaan dan tempat kerjanya akan menggunakan alat ukur Utrecht Work Engagement Scale (UWES) dari Schaufeli, Bakker dan Salanova (2006) yang terdiri dari 3 dimensi yaitu vigor (VI) sebanyak 6 item, dedication (DE) sebanyak 5 item, absoprtion (AB) sebanyak 6 item. Alat ukur ini merupakan alat ukur yang telah dievaluasi oleh Schaufeli, Bakker dan Salanova (2006) yang sebelumnya terdiri dari 24 item yang dikembangkan oleh Schaufeli, Salanova dan rekan-rekan di tahun 2002. Menggunakan skala Likert yang terdiri dari skala 1 adalah Tidak Pernah, skala 2 adalah Jarang, skala 3 adalah Terkadang, skala 4 adalah Sering, skala 5 adalah Sangat Sering dan skala 6 adalah Selalu. Skala Likert yang digunakan oleh Schaufeli, Bakker dan Salanova adalah sebanyak 7 skala yaitu dimulai dari skala 0 (Tidak Pernah) sampai skala 6 (Selalu). Pada penelitian ini, peneliti menggunakan 6 skala untuk menghindari adanya kecenderungan responden memilih skala tengah.

\section{ANALISIS \& HASIL}

Total responden yang masuk dalam data gform sebanyak 281 orang, yang terdiri 4 orang tidak bersedia berpartisipasi dan sebanyak 77 orang tidak sesuai dengan kriteria yang dibutuhkan sehingga harus dikeluarkan dari pengolahan data. Jumlah responden yang dipakai untuk pengolahan data menjadi sebanyak 200 orang $(n=200)$ dengan data demografis yaitu jumlah perempuan sebanyak 120 orang $(60 \%)$ dan laki-laki sebanyak 80 orang (40\%). Pendidikan terakhir S1 sebanyak 178 orang (89\%) dan S2 sebanyak 22 orang (11\%). Pengalaman kerja antara 2-5 tahun sebanyak 153 orang (76\%), 6-10 tahun sebanyak 36 orang (18\%), 11-15 tahun sebanyak 7 orang (4\%) dan 16-20 tahun sebanyak 4 orang $(2 \%)$.

Hasil pengolahan data untuk variabel stres kerja, didapatkan untuk semua item adalah valid dengan nilai signifikansi $99 \%$. Secara keseluruhan, nilai mean $=72.89$ dan nilai $\mathrm{SD}=13.592$. Nilai cronbach's alpha $=$ .830. Hasil dari pengolahan data variabel kesejahteraan di tempat kerja, didapatkan untuk semua item adalah valid dengan nilai signifikansi 99\%. Nilai keseluruhan untuk mean $=55.32$ dan $\mathrm{SD}=9.882$. Nilai Cronbach's alpha $=.863$. Hasil dari pengolahan data variabel keterikatan kerja, didapatkan untuk semua item adalah valid dengan nilai signifikansi 99\%. Keseluruhan nilai mean $=68.57$ dan $\mathrm{SD}=13.215$. Nilai Cronbach's alpha $=0.922$. Menurut Kaplan dan Sacuzzo (1993, dalam Matahari dan Salendu, 2013), jika nilai reliabilitas diatas 0.7 maka alat ukur tersebut baik. Maka dapat dikatakan bahwa ketiga alat ukur tersebut reliabel.

Setelah itu peneliti melakukan pengolahan data ketiga variabel yaitu variabel stres kerja sebagai IV (X), kesejahteraan di tempat kerja sebagai MV (M), dan keterikatan kerja sebagai DV (Y) menggunakan prosedur Process versi 3.00 di SPSS versi 23 untuk melihat nilai effect dan signifikansi antar variabel pada direct effect serta indirect effect dari variabel-variabel tersebut dan untuk melihat nilai yang membuktikan variabel kesejahteraan kerja sebagai mediator stres kerja dan keterikatan kerja.

Hasil pengolahan data membuktikan bahwa pada direct effect (IV terhadap DV 
dengan adanya MV, ditandai huruf c' pada figure 1), variabel IV terhadap MV (yaitu ditandai huruf a pada figur 1), variabel MV terhadap DV (ditandai huruf $\mathrm{b}$ pada figure 1), memiliki nilai $\mathrm{p}<0.05$, hal ini menunjukan bahwa stres kerja memiliki pengaruh signifikan terhadap keterikatan kerja dengan adanya kesejahteraan di tempat kerja, stres kerja memiliki pengaruh yang signifikan terhadap kesejahteraan di tempat kerja, dan kesejahteraan di tempat kerja memiliki pengaruh yang signifikan terhadap keterikatan kerja.

Nilai untuk membuktikan bahwa variabel kesejahteraan di tempat kerja sebagai mediator antara variabel stres kerja dan keterikatan kerja dilihat dari indirect effect $(s)$ of $X$ on $Y$, dengan nilai BootLLCI = -.2454 dan BootULCI = -.0687.

Berdasarkan hasil pengolahan data tersebut, untuk menjawab pertanyaan hipotesis: Apakah variabel kesejahteraan di tempat kerja memediasi variabel stres kerja dan keterikatan kerja, maka jawaban untuk pertanyaan hipotesis tersebut adalah: Ya, variabel ksejahteraan memediasi variabel stres kerja dan keterikatan kerja karena nilai BootLLCI $=-.2454$ dan BootULCI $=-.0687$ pada indirect effect(s) of $X$ on $Y$.

Maka variabel kesejahteraan kerja merupakan mediator untuk variabel stres kerja dan keterikatan kerja yaitu arah pengaruh $\mathrm{X}$ ke $\mathrm{Y}$ melalui $\mathrm{M}$. Arahnya dari anteseden $\mathrm{X}$ ke konsekuensi $\mathrm{M}$, dari anteseden $M$ ke konsekuensi $Y$. Y dipengaruhi oleh $\mathrm{X}$ melalui urutan sebabakibat dimana $X$ mempengaruhi $M$ yang akan mempengaruhi Y (Hayes, 2013).

\section{DISKUSI}

Penelitian ini bertujuan untuk membuktikan variabel kesejahteraan di tempat kerja sebagai mediator untuk variabel stres kerja terhadap variabel keterikatan kerja. Pada penelitian-penelitian sebelumnya yang sudah dilakukan oleh Rothmann (2008) dan Narainsamy dan Westhuizen (2013) mengungkapkan bahwa stres memiliki pengaruh yang signifikan dengan keterikatan kerja. Pada hasil pengolahan data menggunakan PROCESS, pada total effect (IV terhadap DV tanpa adanya MV), menunjukan nilai effect $=$ .0125 , dengan $\mathrm{p}=0.8563$ yang menunjukan tidak ada pengaruh yang signifikan $X$ terhadap $Y$ karena $p>0.05$. Hal tersebut berbanding terbalik dengan penelitian yang sudah dilakukan oleh Rothmann (2008) dan Narainsamy dan Westhuizen (2013) yang menyebutkan bahwa stres memiliki pengaruh yang signifikan dengan keterikatan kerja. Schaufeli (2012) juga mengungkapkan bahwa keterikatan kerja dianggap sebagai bentuk stres yang positif atau eustres karena keterikatan kerja merupakan kondisi pikiran yang terkait dengan pekerjaan yang positif ditandai dengan semangat (vigor), dedikasi (dedication), dan absorpsi (absorption). Artinya, stres memiliki pengaruh terhadap keterikatan kerja, tetapi hal tersebut tidak muncul pada hasil pengolahan data yang dilakukan peneliti.

Kemungkinan tidak adanya pengaruh yang signifikan antara stres kerja dengan keterikatan kerja disebabkan alat ukur stres kerja ini yang masih termasuk baru yaitu tahun 2016 dan alat ukur ini berbeda dengan yang dipakai Rothmann (2008) dan Narainsamy dan Westhuizen (2013) untuk mengukur stres kerja. Hal ini mungkin juga terjadi dikarenakan alat ukur ini dikembangkan di India dan perlu disesuaikan dengan budaya Indonesia. Menurut Shukla dan Srivastava (2016) yang merupakan pengembang alat ukur stres kerja yang dipakai dalam penelitian ini, pengembangan alat ukur stres kerja ini berdasarkan stresor terbaru yang tidak meliputi skala-skala pada penelitian sebelumnya, sehingga Shukla (2016) menambahkan dimensi-dimensi yang terkait dengan stres pada skala yang sesuai dengan negaranya yaitu India. Shukla dan Srivastava (2016) mengembangkan alat ukur stres kerja ini untuk adalah untuk mengidentifikasi potensi stresoruntuk penduduk India. Studi Shukla dan Srivastava (2016) ini mengidentifikasi stresor penting dari studi sebelumnya dan memperkenalkan 
stresor yang baru di kalangan karyawan India. Sehingga, hasil dari alat ukur stres kerja ini berbeda dengan alat ukur stres kerja yang lainnya yang hasilnya memiliki pengaruh terhadap keterikatan kerja seperti yang dipakai oleh Rothmann (2008) serta Narainsamy dan Westhuizen (2013).

Hasil penelitian ini, menunjukan bahwa variabel stres kerja ini jika dihubungkan dengan mediator yaitu variabel kesejahteraan di tempat kerja maka hasilnya menunjukan adanya pengaruh yang signifikan dengan keterikatan kerja dengan nilai $\mathrm{p}=0.0204(\mathrm{p}<0.05)$. Hal tersebut terdapat pada hasil direct effect yaitu pengaruh $\mathrm{X}$ terhadap $\mathrm{Y}$ melalui $\mathrm{M}$ sebagai mediator. Hal ini menunjukan bahwa stres kerja dapat mempengaruhi keterikatan di tempat kerja dengan adanya mediator yaitu kesejahteraan di tempat kerja. Seperti yang diungkapkan oleh Coetzee dan Villiers (2010) bahwa masalah yang berhubungan dengan stres kerja secara negatif mempengaruhi kesejahteraan di tempat kerja dan keterikatan kerja.

Teori yang dikemukakan oleh Rothmann (2008) serta Narainsamy dan Westhuizen (2013) mengenai adanya pengaruh antara stres kerja dengan keterikatan kerja dapat dikatakan sesuai jika adanya mediator yaitu kesejahteraan di tempat kerja. Frith (2017) menyatakan bahwa stres yang tinggi di tempat kerja dapat berdampak negatif terhadap keterikatan kerja. Frith (2017) juga menyebutkan bahwa kebahagiaan di tempat kerja serta kesehatan, termasuk kesehatan mental, memiliki hubungan yang erat. Sehingga organisasi atau perusahaan yang mementingkan kesehatan karyawan, akan membangun sebuah budaya untuk kesejahteraan dan kebahagiaan karyawannya yang akan meningkatkan keterikatan kerja serta produktifitas.

\section{SIMPULAN}

Hasil penelitian menunjukan bahwa stres kerja tidak memiliki pengaruh yang signifikan terhadap keterikatan kerja. Akan tetapi, stres kerja memiliki pengaruh yang signifikan terhadap keterikatan kerja apabila melalui kesejahteraan di tempat kerja sebagai mediator. Kesejahteraan di tempat kerja sebagai variabel mediasi, terbukti memediasi stres kerja dengan keterikatan kerja dilihat dari indirect effect(s) of $X$ on $Y$, dengan nilai BootLLCI $=-.2454$ dan BootULCI $=-.0687$. Variabel stres kerja membutuhkan variabel mediasi yaitu kesejahteraan di tempat kerja untuk dapat mempengaruhi keterikatan di tempat kerja.

\section{SARAN}

Untuk penelitian selanjutnya, alat ukur stres kerja ini dapat diukur kembali dan disesuaikan dengan budaya Indonesia serta melakukan pengujian kembali untuk melihat pengaruh stres kerja terhadap keterikatan kerja tanpa adanya mediator. Hal ini untuk melihat apakah di Indonesia, Jakarta khususnya, stres kerja berpengaruh secara signifikan tanpa adanya mediator atau membutuhkan mediator. Hal ini untuk penelitian selanjutnya apabila ingin meneliti hubungan variabel stres kerja dengan variabel keterikatan kerja.

Hasil dari penelitian ini membuktikan bahwa apabila karyawan yang mengalami stres di pekerjaannya maka kesejahteraan psikologis akan terganggu yang dapat mempengaruhi kesejahteraan fisik yang pada akhirnya akan mempengaruhi keterikatan kerja. Hal ini dapat berguna untuk organisasi atau perusahaan untuk tidak membuat para pekerja terlalu stres misalnya karena adanya beban kerja tinggi, tenggat waktu yang terlalu dekat ataupun tuntutan pekerjaan yang tinggi tanpa disesuaikan dengan sumber daya yang ada. Karyawan yang stres akan tidak nyaman dengan kesejahteraan dirinya dan tempat kerjanya yang dapat mempengaruhi rekan kerja yang lain. Pada akhirnya hal itu akan membuat mereka tidak merasa terikat dengan organisasi. Organisasi atau perusahaan diharapkan dapat mengambil langkah komprehensif untuk mengatasi masalah stres yang dihadapi para karyawannyaagar para karyawan dapat bekerja lebih produktif yang akan 
memberikan keuntungan untuk organisasi atau perusahaan.

\section{DAFTAR PUSTAKA}

Arnold, J., Randall, R., Patterson, F., Silvester, J., Robertson, I., Cooper, C., . . Hartog, a. D. (2010). Work Psychology: Understanding Human Behavior in the Workplace, Fifth Edition. Essex: Pearson Education Limited.

Arshadi, N., \& Damiri, H. (2013). The Relationship of Job Stress with Turnover Intention and Job Performance: Moderating Role of OBSE. Procedia - Social and Behavioral Sciences 84, 706-710.

Bakker, A. B., Schaufeli, W. B., Leiter, M. P., \& Taris, T. W. (2008). Work engagement: An emerging concept in occupational health psychology. Work \& Stress Vol. 22, No. 3, 187-200.

Bell, A. S., Rajendran, D., \& Theiler, S. (2012). Job Stress, Well-being, Work-Life Balance and Work-Life Conflict Among Australian Academics. Electronic Journal of Applied Psychology, 25-37.

Chacko, R. V. (2015). The Influence of Purpose in Work-Life, Job Engagement, and Meaningfulness on Cognitive, Affective, and Behavioral Well-Being: A Regulatory Focus Theory Approach. Oklahoma, USA: Dissertation, Faculty of the Graduate College, Oklahoma State University.

Coetzee, M., \& Villiers, M. d. (2010). Sources of job stress, work engagement and career orientations of employees in a South African fi nancial institution. Southern African Business Review Volume 14 Number 1, 27-58.

Diener, E., Heintzelman, S. J., Kushlev, K., Tay, L., Wirtz, D., Lutes, L. D., \& Oishi, S. (2016). Findings All Psychologists Should Know From The New Science on Subjective Well-Being. Canadian Psychology, 2-42.
Finney, C., Stergiopoulos, E., Hensel, J., Bonato, S., \& Dewa, C. S. (2013). Organizational stressors associated with job stress and burnout in correctional officers: a systematic review. $B M C$ Public Health.

Frith, B. (2017, March 21). Stress affecting employee engagement. Retrieved from HR Magazine: http://hrmagazine.co.uk/articledetails/stress-affecting-employeeengagement

Gravetter, F. J., \& Forzano, L.-A. B. (2012). Research Methods for the Behavioral Sciences, 4th edition. Belmont, CA: Wadsworth, Cengage Learning.

Gravetter, F. J., \& Wallnau, L. B. (2013). Statistics for the Behavioral Sciences, 9th edition. Belmont, USA: Wadsworth, Cengage Learning.

Hakanen, J. J., \& Schaufeli, W. B. (2012). Do burnout and work engagement predict depressive symptoms and life satisfaction? A three-wave seven-year prospective study. Journal of Affective Disorders.

Hayes, A. F. (2013). Introduction to Mediation, Moderation, and Conditional Process Analysis. New York: The Guilford Press.

Ikonne, C. N. (2015). Job Stress and Psychological Well-Being among Library Employees: A Survey of Library Staff in Selected University Libraries in South-West Nigeria . Open Access Library Journal, Vol. 2.

Iqbal, T., Khan, K., \& Iqbal, N. (2012). Job Stress \& Employee Engagement. European Journal of Social Sciences, ISSN 1450-2267, Vol. 28, No. 1, 109118.

Khairuddin, S. M., \& Nadzri, F. H. (2017). Stress and Work Engagement: A Conceptual Study on Academics in Malaysians Private Universities. International Journal of Innovation in Enterprise System, Volume 01, Issue 01, 7-12. 
Krohne, H. W. (2002). Stress and Coping Theories. Johannes GutenbergUniversität Mainz Germany.

Kurniawati, I. D. (2014). Masa Kerja dengan Job Engagement pada Karyawan. Jurnal Ilmiah Psikologi Terapan, Vol. 02, No. 02, 311-324.

Laschinger, H. K., \& Fida, R. (2014). New nurses burnout and workplace wellbeing: The influence of authentic leadership and psychological capital. Burnout Research 1, 19-28.

Matahari, W. A., \& Salendu, A. (2013). Hubungan antara Workplace Wellbeing dan Vocational Identity pada Perawat. Fakultas Psikologi, Universitas Indonesia.

Meyer, A. G. (2012). Meningkatkan Keterikatan Kerja Melalui Intervensi Terhadap Kegiatan Berbagi Pengetahuan - Studi Mengenai Asesor Unit Kerja XYZ di PT. $A B C$ Indonesia. Depok: Thesis, Faculty of Psychology, Universitas Indonesia.

Moulisa, K., \& Sjabadhyni, B. (2013). Hubungan antara Workplace WellBeing dan Chinese Value pada Karyawan Keturunan Chinese. Fakultas Psikologi, Universitas Indonesia.

Narainsamy, K., \& Westhuizen, S. V. (2013). Work Related Well-Being: Burnout, Work Engagement, Occupational Stress and Job Satisfaction Within A Medical Laboratory Setting. Journal Psychology in Africa, 23(3), 467-474. doi:10.1080/14330237.2013.10820653

Orgambídez-Ramos, A., Borrego-Alés, Y., \& Mendoza-Sierra, I. (2014). Role Stress and Work Engagement as Antecedents of Job Satisfaction in Spanish Workers. Journal of Industrial Engineering and Management, 7(1), 360-372.

Page, K. (2005). Subjective Wellbeing in the Workplace. Thesis, School of Psychology, Faculty of Health and Behavioural Sciences, Deakin University.

Page, K. M., \& Vella-Brodrick, D. A. (2009). The 'What', 'Why', and 'How' of
Employee Well-Being: A New Model. Social Indicators Research, Vol. 90, No. 3, 441-458.

Pocnet, C., Antonietti, J.-P., Massoudi, K., Györkös, C., Becker, J., Bruin, G. P., \& Rossier, J. (2015). Influence of Individual Characteristics on Work Engagement and Job Stress in a Sample of National and Foreign Workers in Switzerland. Swiss Journal of Psychology, Vol. 74, Issue 1, 17-27.

Robbins, S. P., \& Judge, T. A. (2015). Organizational Behavior - Global Edition, 16th edition. Harlow, Essex: Pearson.

Robertson, I. T., Birch, A. J., \& Cooper, C. L. (2012). Job and Work Attitudes, Engagement and Employee Performance: Where Does Psychological Well-Being Fit In? Leadership \& Organization Development Journal, Vol. 33, No. 3, 224-232.

Rothmann, I., \& Cooper, C. (2008). Organizational and Work Psychology . London: Hodder Education.

Rothmann, S. (2008). Job Satisfaction, Occupational Stress, Burnout and Work Engagement as Components of WorkRelated Wellbeing. SA Journal of Industrial Psychology, Vol. 34, No. 3, 34(3), 11-16.

Schaufeli, W. B. (2012). Work Engagement: What Do We Know and Where Do We Go? Romanian Journal of Applied Psychology, Vol. 14, No. 1, 3-10.

Schaufeli, W. B., Bakker, A. B., \& Salanova, M. (2006). The Measurement of Work Engagement With a Short Questionnaire: A Cross-National Study. Educational and Psychological Measurement Volume 66 Number 4, 701-716.

Shimazu, A., Schaufeli, W. B., Kubota, K., \& Kawakami, N. (2012). Do Workaholism and Work Engagement Predict Employee Well-Being and Performance in Opposite Direction? National 
Institute of Occupational Safety and Health, Industrial Health, 50, 316-321.

Shuck, B., \& Jr., T. G. (2014). Employee Engagement and Well-Being: A Moderation Model and Implications for Practice. Journal of Leadership \& Organizational Studies, Vol. 21 (1), 43 58.

Shukla, A., \& Srivastava, R. (2016). Development of short questionnaire to measure an extended set of role expectation conflict, coworker support and work-life balance: The new job stress scale. Cogent Business \& Management.

Stranks, J. (2005). Stress at Work, Manajemen and Prevention. Burlington, MA: Elseiver Butterworth-Heinemann.

Sungkit, F. N., \& Meiyanto, I. S. (2015). Pengaruh Job Enrichment terhadap Employee Engagement melalui Psychological Meaningfulness sebagai Mediator. Gadjah Mada Journal of Psychology, Volume 1, No. 1, 61-73.

Zheng, X., Zhu, W., Zhao, H., \& Zhang, C. (2015). Employee well-being in organizations: Theoretical model, scale development, and cross-cultural validation. Journal of Organizational Behavior, 621-644. 